\title{
Antibiotic Sensitivity Pattern of Bacterial Isolates in Patients with Chronic Rhinosinusitis in Kaduna, Nigeria
}

\author{
Emmanuel Musa ${ }^{1} \quad$ Aliyu Mohammed Kodiya ${ }^{2} \quad$ Abdullahi Musa Kirfi ${ }^{3}$ Onyekwere George B. Nwaorgu ${ }^{4}$ \\ ${ }^{1}$ Department of Otorhinolaryngology, Maitama District Hospital, \\ Federal Capital Territory Administration, Abuja, Nigeria \\ 2 Department of Otorhinolaryngology, College of Medical Sciences, \\ University of Maiduguri, Maiduguri, Nigeria \\ ${ }^{3}$ Department of Clinical Services, National Ear Care Centre, Kaduna, Nigeria \\ ${ }^{4}$ Department of Otorhinolaryngology, College of Medicine, \\ University of Ibadan, Ibadan, Nigeria \\ Address for correspondence Dr Abdullahi Musa Kirfi, MBBS, FWACS, \\ Department of Clinical Services, National Ear Care Centre, P.M.B 2438, \\ Kaduna, Nigeria (e-mail: abdulkirfi@yahoo.co.uk). \\ Int Arch Otorhinolaryngol 2019;23:152-156.
}

\begin{abstract}
Introduction A common practice in the management of patients with chronic rhinosinusitis (CRS), the empirical use of antibiotics may contribute to treatment failure and to the development of antimicrobial resistance.

Objective To determine the antibiotic sensitivity pattern of aerobic and anaerobic bacteria associated with CRS.

Methods This was a prospective cross-sectional study in which endoscopically guided middle meatal swabs (IBM Spss, version 16.0, Chicago, IL, USA) were aseptically taken from patients diagnosed with CRS after obtaining informed consent and ethical clearance. The samples were sent to the laboratory for qualitative and semiquantitative analysis via gram stain, aerobic, anaerobic cultures and antibacterial sensitivity tests. The collected data was analyzed using SPSS for Windows, version 16 (SPSS Inc, Chicago, IL, USA). Simple statistical parameters and paired sample $t$-test were used, as appropriate.

\section{Keywords}

- antibacterial agent

- amoxicillin-potassium clavulanate combination

- bacteria

- anaerobic

- sinusitis

Results There were 74 (56.92\%) bacterial growths, out of which 55 (74.32\%) were aerobic and 19 (25.68\%) were anaerobic isolates, from a total of 130 patients. About 13 (17.5\%$18 \%$ ) of these bacterial growths yielded a mixed growth of aerobic and anaerobic isolates. The most common bacterial isolates were 26 (35.14\%) Staphylococcus aureus, Haemophilus influenzae 9 (12.16\%), Streptococcus viridians 8 (10.81\%), and Streptococcus pneumoniae 5 (6.76\%). Augmentin, ciprofloxacin, and Peflacine were found to be most effective, followed by levofloxacin, Rocephin, erythromycin and Zinat in that order.

Conclusion Augmentin, ciprofloxacin and Peflacine have a sensitivity of $100 \%$, while most of the organisms show resistance to Ampiclox, amoxicillin, and Septrin.
\end{abstract}

\section{Introduction}

Chronic rhinosinusitis (CRS) is a clinical disorder that encompasses a heterogeneous group of infections and inflammatory conditions affecting the nose and the paranasal sinuses. ${ }^{1-3}$ Chronic rhinosinusitis is a common disease in

received

August 29, 2017

accepted

July 31, 2018

published online

October 25, 2018
DOI https://doi.org/

10.1055/s-0038-1673676. ISSN $1809-9777$. otorhinolaryngologic practice worldwide. ${ }^{2}$ Antibiotics are prescribed empirically, which could result in treatment failure and in the development of antimicrobial resistance., ${ }^{4,5}$

In 1996, the multidisciplinary Rhinosinusitis Task Force of the American Academy of Otolaryngologists, Head and Neck Surgeons (AAO-HNS $)^{6}$ proposed a clinical diagnosis of CRS as a
Copyright $(\underset{2019}{ } 201$ by Thieme Publicações License terms Ltda, Rio de Janeiro, Brazil
(1) $\Theta \circledast$ 
continuous inflammation of the mucosa of the nose and of the paranasal sinuses with at least 2 major and 1 minor criteria or 2 minor and 1 major criteria for at least 12 consecutive weeks. ${ }^{7}$ The major criteria include nasal obstruction/blockage, nasal discharge/purulence/discolored postnasal drainage, hyposmia/anosmia, facial pain/pressure, and purulence in the nasal cavity on examination. The minor criteria are headache, fever, halitosis, dental pain, cough and ear pain/pressure/fullness.

The Sinus and Allergy Health Partnership (SAHP) ${ }^{8}$ upheld the proposal of the AAO-HNS and put forward that objective evidence of inflammation must be present and identified in association with the ongoing symptoms. Hence, a nasal endoscopy and a computed tomography (CT) scan of the paranasal sinuses or a plain occipitomental (OM) view sinus radiograph should be necessary as means of supporting the diagnosis of adult CRS.

Bacteria, fungi or viruses may be involved in many cases, but there may be some cases with no identifiable pathogenic organism. Generally, pathogen-positive cultures are recovered in 50 to $60 \%$ of the patients with CRS. ${ }^{9,10}$ In Nigeria, while a study in Ilorin ${ }^{4}$ showed that $45 \%$ of the patients with CRS had pathogenic isolates using a posterior nasal swab, another study in Sokoto ${ }^{5}$ showed that infective causes accounted for $67.1 \%$ of the cases of CRS. The study from Ilorin ${ }^{4}$ showed sensitivity to ofloxacin, cefuroxime and resistance to penicillins. Amoxicillin-clavulanate was also shown to be effective in CRS.

Antibiotics are by far the most commonly prescribed drugs for CRS. ${ }^{1,11}$ The selection of these antibiotics is usually empirical, sometimes with inadequate dose and duration of treatment. To treat patients adequately and to prevent the development of resistance, it is necessary to prescribe the appropriate antimicrobial for the appropriate duration based on the antibiotic sensitivity of the pathogens involved. Therefore, the identification of these pathogens should form the basis of prescribing antibiotics. The present study aims to determine the antibiotic sensitivity pattern in patients with CRS seen at the study center.

\section{Methods}

This was a prospective cross-sectional descriptive study aimed at determining the sensitivity pattern of bacterial isolates associated with CRS among patients suffering from this condition. The research was conducted at the study center in the the National Ear Care Centre from samples collected by endoscopically-guided middle meatal swabs (Karl Storz, Germany). Ethical clearance was obtained from the institutional Health Research Ethics Committee (HREC). Middle meatal swabs from 130 patients with CRS were analyzed microbiologically to determine the common pathogens. The study population included male and female patients attending the clinic of the study center who met the diagnostic criteria of CRS according to the multidisciplinary Rhinosinusitis Task Force of the AAOHNS $^{6}$ as modified by the Sinus and Allergy Health Partnership (SAHP). ${ }^{8}$ A plain OM view sinus radiograph of the paranasal sinuses was used for supporting the diagnosis of CRS. Consecutive patients seen by the researchers in the study center with diagnosis of CRS from November 2013 to May 2014 who satisfied the inclusion criteria were recruited.
A structured questionnaire based on the research questions was employed for the present study. A DARAY HL 550 medical examination headlight (Daray Ltd., Derbyshire, UK) served as the light source for the physical examination. A Thudicum nasal speculum was used for anterior rhinoscopy; rigid endoscopes in sizes $2.7 \mathrm{~mm}$ and $4 \mathrm{~mm}, 0^{\circ}$ and $30^{\circ}$ were used for nasal endoscopy, and an endoscopically-guided middle meatal swab was used for the collection of samples. Local anesthesia, vasoconstriction, and decongestion were achieved with $10 \%$ xylocaine spray and $2 \%$ lignocaine in adrenalin at 1:200,000 dilution.

A 10-milliliters syringe filled with normal saline solution was then used to irrigate the nasal cavities, and then a sterile swab stick was used to take the swab from the middle meatus. The collected swab was inoculated on to the culture media: Chocolate agar and macConkey agar for aerobic cultures; cooked meat agar and blood agar for anaerobic cultures.

An oxygen absorbing and carbon-dioxide generating Master Anaerobic GasPak (Micromaster Laboratories PVT, Maharashtra, India) was used for anaerobic culture, while an Equitron anaerobic jar (Equitron Medica Private Limited, Mumbai, India) was used for the incubation and the rearing of anaerobes.

The antibiotic sensitivity test was performed by the diffusion method ${ }^{12}$ using a Multidisk maxidisc high profile + ve (Maxicare medical laboratory, Nigeria), including Peflacine (10 $\mu \mathrm{g})$, gentamycin $(10 \mu \mathrm{g})$, Ampiclox $(30 \mu \mathrm{g})$, Zinacef $(20 \mu \mathrm{g})$, Rocephin $(25 \mu \mathrm{g})$, ciprofloxacin $(10 \mu \mathrm{g})$, streptomycin $(30 \mu \mathrm{g})$, Septrin $(30 \mu \mathrm{g})$, erythromycin $(10 \mu \mathrm{g})$, and negative including Septrin $(30 \mu \mathrm{g})$, chloramphenicol $(30 \mu \mathrm{g})$, sparfloxacin $(10 \mu \mathrm{g})$, ciprofloxacin $(10 \mu \mathrm{g})$, amoxicillin $(30 \mu \mathrm{g})$, gentamycin $(10 \mu \mathrm{g})$, pefloxacin $(30 \mu \mathrm{g})$, Tarivid $(10 \mu \mathrm{g})$ and streptomycin $(30 \mu \mathrm{g})$. Other single-disc antibiotic-sensitivity tests included metronidazole and Augmentin. The reading was based on the zone of inhibition measured in millimeters using a calibrated ruler, using an interpretative chart of zone sizes according to the antibiotics, and were graded as sensitive $(+++)$, intermediate $(++)$, or resistant.

\section{Results}

A total of 130 patients with CRS were studied. The age range was between 18 and 55 years old, with a mean age of $31.87 \pm 8.60$ years old. The sample consisted of 67 (51.5\%) males and 63 (48.5\%) females, with a male to female ratio of 1.1:1, as shown in - Table 1.

Table 1 Age and gender distribution of study group

\begin{tabular}{|l|l|l|l|}
\hline \multirow{2}{*}{$\begin{array}{l}\text { Group age } \\
\text { (years) }\end{array}$} & \multicolumn{2}{|l|}{ Gender } & \multirow{2}{*}{ Total } \\
\cline { 2 - 3 } & Male & Female & \\
\hline $11-20$ & 4 & 13 & 17 \\
\hline $21-30$ & 34 & 17 & 51 \\
\hline $31-40$ & 19 & 25 & 44 \\
\hline $41-50$ & 8 & 8 & 16 \\
\hline $51-60$ & 2 & - & 2 \\
\hline Total & $67(51.5 \%)$ & $63(48.5 \%)$ & $130(100 \%)$ \\
\hline
\end{tabular}


Table 2 History of antibiotic usage for chronic rhinosinusitis by the patients studied

\begin{tabular}{|l|l|l|}
\hline Types of Antibiotic & Frequency & Percentage (\%) \\
\hline Ampiclox & 28 & 21.5 \\
\hline Amoxicilin & 23 & 17.7 \\
\hline Augmentin & 11 & 8.5 \\
\hline Metronidazole & 5 & 3.8 \\
\hline Ciprofloxacin & 4 & 3.1 \\
\hline Cefuroxime & 3 & 2.3 \\
\hline Total & 74 & 56.9 \\
\hline${ }^{* * *}$ Missing System & 56 & 43.1 \\
\hline Total & 130 & 100.0 \\
\hline
\end{tabular}

*** Those without empirical treatment with antibiotics in the last 6 months prior to the otolaryngology consultation.

The history of empirical treatment of the CRS patients with antibiotics in the last 6 months prior to the ear, nose, and throat (ENT) consultation is shown in - Table 2. About $57 \%$ of the patients admitted to the use of antibiotics (mostly Ampiclox and amoxicillin) before the ENT consultation, as shown in - Table 2

-Table 3 shows the distribution of various bacterial isolates. There were 74 (56.92\%) positive bacterial growths

Table 3 Distribution of various isolates in participants

\begin{tabular}{|l|l|}
\hline Species & $\begin{array}{l}\text { Swab specimen of } \\
\text { patients }\end{array}$ \\
\cline { 2 - 2 } & Frequency (\%) \\
\hline Bacterial isolates & $(n=74)$ \\
\hline Aerobic bacterial isolates & \\
\hline Gram positive & \\
\hline Staphylococcus aureus & $26(35.14 \%)$ \\
\hline Coagulase negative staphylococcus & $4(5.41 \%)$ \\
\hline Streptococcus viridans & $8(10.81 \%)$ \\
\hline Streptococcus pneumonia & $5(6.76 \%)$ \\
\hline Gram negative & \\
\hline Haemophilus influenzae & $9(12.16 \%)$ \\
\hline Pseudomonas aeruginosa & $1(1.35 \%)$ \\
\hline Neisseria specie & $2(2.70 \%)$ \\
\hline Total aerobic bacteria & $55(74.32 \%)$ \\
\hline Anaerobic bacterial isolates & \\
\hline Gram positive & \\
\hline Peptostreptococcus & $8(10.81 \%)$ \\
\hline Anaerobic bacillus & $5(6.76 \%)$ \\
\hline Gram negative & $6(8.11 \%)$ \\
\hline Bacteroides spp & $19(25.68 \%)$ \\
\hline Total anaerobic bacterial isolates & $74(100 \%)$ \\
\hline Total bacterial isolates & \\
\hline & \\
\hline & \\
\hline & \\
\hline & \\
\hline & \\
\hline
\end{tabular}

among the 130 subjects, out of which 55 (74.32\%) were aerobic and 19 (25.68\%) were anaerobic. About $18 \%$ of these positive bacterial growths yielded a mixed growth of aerobic and anaerobic isolates. The most common bacterial isolates were Staphylococcus aureus (35.14\%), Haemophilus influenzae (12.16\%), Streptococcus viridians (10.81\%) and Streptococcus pneumonia 5 (6.76\%).

- Tables $\mathbf{4}$ and $\mathbf{5}$ show the antibiotic sensitivity pattern of the studied bacterial isolates. Augmentin, ciprofloxacin, and Peflacine were found to be the most effective, with $100 \%$ sensitivity, followed by levofloxacin, Rocephin, erythromycin, and Zinat, in that order, showing intermediate sensitivity. Most isolates were resistant to Ampiclox, Amoxil and Septrin.

\section{Discussion}

Culture targeted therapy based on the antibiotic sensitivity of the pathogens identified in patients with CRS remains the gold standard if cure is the primary aim of the treatment.

In the present study, there were 74 (56.92\%) bacterial growths, of which 55 (74.32\%) were aerobic, and 19 (25.68\%) were anaerobic. This falls within the global average rate of between 50 and $60 \%$ in the recovery of bacterial growth in CRS. ${ }^{9,10}$ However, this is higher than the findings of Ologe et al in Ilorin, who reported a prevalence of $45 \%$ of bacterial growth in patients with CRS. ${ }^{4}$ The difference could be either because only aerobic bacteria were evaluated in that study or due to a difference in the geopolitical area.

The most common bacterial isolates were $S$. aureus (35.14\%), H. influenzae (12.16\%), S. viridians (10.81\%) and S. pneumonia 5 (6.76\%). These findings are similar to those reported in the study by Araujo et $\mathrm{al}^{13}{ }^{13}$ in Brazil, in which S. aureus (31\%) was the most common aerobe found. However, it is lower than the prevalence of $48.1 \%$ reported by Ologe et $\mathrm{al}^{4}{ }^{4}$ who used swabs from the posterior nasal fossa instead of the middle meatal swab used in the present study.

In the present study, Augmentin, ciprofloxacin and Peflacine were found to be most effective. Rocephin, levofloxacin, erythromycin and Zinat were effective but not as effective as the first three. This suggests that levofloxacin may not be as effective as other quinolones in the treatment of CRS. Therefore, there is a need for further studies to verify its efficacy in CRS. In the present study, Zinat showed intermediate sensitivity to most isolates. There was resistance to Ampiclox, Amoxil and Septrin. The penicillins were similarly found to be least sensitive in a study by Ologe et $\mathrm{al}^{4}$ in Ilorin, where ofloxacin had $100 \%$ sensitivity. Kamau et al $^{14}$ reported that erythromycin, cefadroxil, chloramphenicol and amoxicillin have high sensitivity, while ampicillin, cotrimoxazole, and pefloxacin had poor sensitivity in Kenya, showing both comparable and contrasting features with the present study. This may be due to a difference in the antibiotic resistance pattern in different geographical regions in the country. The fact that the isolates in the present study are less susceptible to cephalosporins than to ciprofloxacin, Peflacin and Augmentin may be due to the anaerobes and gramnegative aerobes, but cross-resistance with penicillins might be a possibility. This resistance is of public health importance 
Table 4 Sensitivity pattern of bacterial isolates in chronic rhinosinusitis

\begin{tabular}{|l|l|l|l|l|l|l|l|}
\hline Isolates tested & Freq & Au & Cp & Pef & E & R & Z \\
\hline Staphylococcus aureus & 27 & $27 \mathrm{~s}$ & $27 \mathrm{~s}$ & $27 \mathrm{~s}$ & $15 \mathrm{~s}, 12 \mathrm{i}$ & $20 \mathrm{~s}, 7 \mathrm{i}$ & $15 \mathrm{~s}, 12 \mathrm{i}$ \\
\hline CONS & 27 & $27 \mathrm{~s}$ & $27 \mathrm{~s}$ & $27 \mathrm{~s}$ & $12 \mathrm{~s}, 15 \mathrm{i}$ & $22 \mathrm{~s}, 5 \mathrm{i}$ & $16 \mathrm{~s}, 11 \mathrm{i}$ \\
\hline Streptococcus viridians & 8 & $8 \mathrm{~s}$ & $8 \mathrm{~s}$ & $8 \mathrm{~s}$ & $7 \mathrm{i}, 1 \mathrm{~s}$ & $6 \mathrm{~s}, 2 \mathrm{i}$ & $5 \mathrm{~s}, 3 \mathrm{i}$ \\
\hline Streptococcus pneumonia & 5 & $5 \mathrm{~s}$ & $5 \mathrm{~s}$ & $5 \mathrm{~s}$ & $5 \mathrm{~s}$ & $4 \mathrm{~s}, 1 \mathrm{i}$ & $5 \mathrm{~s}$ \\
\hline Haemophilus influenzae & 9 & $9 \mathrm{~s}$ & $9 \mathrm{~s}$ & $9 \mathrm{~s}$ & $9 \mathrm{~s}$ & $9 \mathrm{~s}$ & $9 \mathrm{i}$ \\
\hline Pseudomonas aeruginosa & 1 & $1 \mathrm{~s}$ & $1 \mathrm{~s}$ & $1 \mathrm{~s}$ & $1 \mathrm{r}$ & $1 \mathrm{r}$ & $3 \mathrm{r}$ \\
\hline Neisseria specie & 3 & $3 \mathrm{~s}$ & $3 \mathrm{~s}$ & $3 \mathrm{~s}$ & $3 \mathrm{~s}$ & $3 \mathrm{~s}$ & $3 \mathrm{~s}$ \\
\hline Peptostreptococcus & 8 & $8 \mathrm{~s}$ & $8 \mathrm{~s}$ & $8 \mathrm{~s}$ & $8 \mathrm{r}$ & $8 \mathrm{r}$ & $8 \mathrm{r}$ \\
\hline Anaerobic bacillus & 5 & $5 \mathrm{~s}$ & $5 \mathrm{~s}$ & $5 \mathrm{~s}$ & $5 \mathrm{r}$ & $6 \mathrm{r}$ & $5 \mathrm{r}$ \\
\hline Bacteroides spp & 6 & $6 \mathrm{~s}$ & $6 \mathrm{~s}$ & $6 \mathrm{~s}$ & $6 \mathrm{r}$ & $6 \mathrm{r}$ \\
\hline Total & 99 & $99 \mathrm{~s}$ & $99 \mathrm{~s}$ & $99 \mathrm{~s}$ & $45 \mathrm{~s}, 34 \mathrm{i}, 20 \mathrm{r}$ & $64 \mathrm{~s}, 15 \mathrm{i}, 20 \mathrm{r}$ & $44 \mathrm{~s}, 35 \mathrm{i}, 20 \mathrm{r}$ \\
\hline
\end{tabular}

Abbreviations: Au, Augmentin; CONS, coagulase negative staphylococcus species; Cp, ciprofloxacin; E, erythromycin; i, intermediate sensitivity; Pef, Peflacine; r, resistant; R, Rocephin; s, sensitive; Z, Zinat.

Table 5 Sensitivity pattern of bacterial isolates in chronic rhinosinusitis

\begin{tabular}{|l|l|l|l|l|l|l|}
\hline Isolates tested & Freq & Ax & Am & S & M & L \\
\hline Staphylococcus aureus & 27 & $10 \mathrm{i}, 17 \mathrm{r}$ & $27 \mathrm{i}$ & $10 \mathrm{~s}, 17 \mathrm{i}$ & $27 \mathrm{i}$ & $21 \mathrm{~s}, 6 \mathrm{i}$ \\
\hline CONS & 27 & $7 \mathrm{i}, 20 \mathrm{r}$ & $20 \mathrm{i}, 7 \mathrm{r}$ & $6 \mathrm{~s}, 21 \mathrm{i}$ & $27 \mathrm{i}$ & $23 \mathrm{~s}, 4 \mathrm{i}$ \\
\hline Streptococcus viridians & 8 & $4 \mathrm{i}, 4 \mathrm{r}$ & $8 \mathrm{i}$ & $8 \mathrm{i}$ & $6 \mathrm{i}, 2 \mathrm{r}$ & $6 \mathrm{~s}, 2 \mathrm{i}$ \\
\hline Streptococcus pneumonia & 5 & $3 \mathrm{i}, 2 \mathrm{r}$ & $4 \mathrm{i}, 1 \mathrm{r}$ & $5 \mathrm{i}$ & $5 \mathrm{i}$ & $4 \mathrm{~s}, 1 \mathrm{~s}$ \\
\hline Haemophilus influenzae & 9 & $2 \mathrm{i}, 7 \mathrm{r}$ & $7 \mathrm{i}, 2 \mathrm{r}$ & $4 \mathrm{i}, 5 \mathrm{r}$ & $9 \mathrm{i}$ & $7 \mathrm{~s}, 2 \mathrm{i}$ \\
\hline Pseudomonas aeruginosa & 1 & $1 \mathrm{r}$ & $1 \mathrm{r}$ & $1 \mathrm{r}$ & $1 \mathrm{~s}$ & $3 \mathrm{i}$ \\
\hline Neisseria specie & 3 & $1 \mathrm{i}, 2 \mathrm{r}$ & $3 \mathrm{~s}$ & $3 \mathrm{i}$ & $8 \mathrm{~s}$ & $2 \mathrm{~s}, 1 \mathrm{i}$ \\
\hline Peptostreptococcus & 8 & $8 \mathrm{r}$ & $8 \mathrm{r}$ & $8 \mathrm{r}$ & $5 \mathrm{~s}$ & $6 \mathrm{~s}, 2 \mathrm{i}$ \\
\hline Anaerobic bacillus & 5 & $5 \mathrm{r}$ & $5 \mathrm{r}$ & $5 \mathrm{r}$ & $6 \mathrm{~s}, 2 \mathrm{i}$ \\
\hline Bacteroides spp & 6 & $6 \mathrm{r}$ & $6 \mathrm{r}$ & $6 \mathrm{r}$ & $20 \mathrm{~s}, 77 \mathrm{i}, 2 \mathrm{~s}$ & $75 \mathrm{~s}, 24 \mathrm{i}$ \\
\hline Total & 99 & $27 \mathrm{i}, 72 \mathrm{r}$ & $3 \mathrm{~s}, 66 \mathrm{i}, 30 \mathrm{r}$ & $16 \mathrm{~s}, 58 \mathrm{i}, 25 \mathrm{r}$ & $\mathrm{i}$ \\
\hline
\end{tabular}

Abbreviations: Am, Amoxil; Ax, Ampiclox; CONS, coagulase negative staphylococcus species; i, intermediate sensitivity; L, levofloxacin; M, metronidazole; r, resistant; s, sensitive; $S$, Septrin.

because the history of antibiotic usage by the patients revealed that $\sim 40 \%$ of the patients with CRS used either Ampiclox or Amoxil prior to the ENT consultation in the present study.

\section{Conclusion}

In the present study, Augmentin, ciprofloxacin and Peflacine have $100 \%$ sensitivity, while most of the organisms show resistance to Ampiclox, amoxicillin and Septrin.

\section{References}

1 Rodney JS, Bradford AW. Chronic Rhinosinusitis and polyposis. In: Ballenger's Otolaryngology, Head and Neck Surgery. 17th Edn (SnowJr JB, Wackym PA eds) B C Decker. Shelton. 2009:573-582

2 Ogunleye AO, Nwargu OG, Lasisi AO, Ijaduola GT. Trends of sinusitis in Ibadan, Nigeria. West Afr J Med 1999;18(04):298-302
3 Mainasara MG, Labaran AS, Kirfi AM, Fufore MB, Fasunla AJ, Grema US. Clinical Profile and Management of Chronic Rhinosinusitis among Adults in Northwestern Nigeria. The American Journal of Innovative Research and Applied Sciences. 2015;1:133-136

4 Ologe FE, Nwabuisi C. Bacteriology of chronic sinusitis in Ilorin, Nigeria. Afr J Clin Exp Microbiol 2003;4:91-97

5 Iseh KR, Makusidi M. Rhinosinusitis: a retrospective analysis of clinical pattern and outcome in north western Nigeria. Ann Afr Med 2010;9(01):20-26

6 Lanza DC, Kennedy DW. Adult rhinosinusitis defined. Otolaryngol Head Neck Surg 1997;117(3 Pt 2):S1-S7

7 Benninger MS. The impact of cigarette smoking and environmental tobacco smoke on nasal and sinus disease: a review of the literature. Am J Rhinol 1999;13(06):435-438

8 Benninger MS, Ferguson BJ, Hadley JA, et al. Adult chronic rhinosinusitis: definitions, diagnosis, epidemiology, and pathophysiology. Otolaryngol Head Neck Surg 2003;129(3, Suppl): S1-S32

9 Benninger MS, Appelbaum PC, Denneny JC, Osguthorpe DJ, Stankiewicz JA. Maxillary sinus puncture and culture in the 
156 Antibiotic Sensitivity Pattern of Bacterial Isolates Musa et al.

diagnosis of acute rhinosinusitis: the case for pursuing alternative culture methods. Otolaryngol Head Neck Surg 2002;127 (01):7-12

10 Talbot GH, Kennedy DW, Scheld WM, Granito K; Endoscopy Study Group. Rigid nasal endoscopy versus sinus puncture and aspiration for microbiologic documentation of acute bacterial maxillary sinusitis. Clin Infect Dis 2001;33(10):1668-1675

11 Cain RB, Lal D. Update on the management of chronic rhinosinusitis. Infect Drug Resist 2013;6:1-14
12 Barrow GL, Feithan RKA. Cowan and Steel's manual for the identification of medical bacteria. 3rd Edition, Cambridge University Press. 1993:106-108

13 Araujo E, Dall C, Cantarelli V, Pereira A, Mariante AR. Microbiology of middle meatus in chronic rhinosinusitis. Braz J Otorhinolaryngol. 2007;73(04):549-555

14 Kamau JK, Macharia IM, Odhiambo PA. Bacteriology of chronic maxillary sinusitis at Kenyatta National Hospital, Nairobi. East Afr Med J 2001;78(07):343-345 